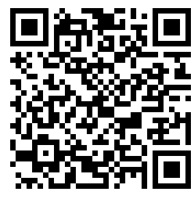

\title{
An Invisible Virus Has Made Visible Many Underestimated Problems in Medical Education and Research
}

\author{
Georgieva L. M. ${ }^{1}$, Borisova B. V. ${ }^{1}$ \\ ${ }^{1}$ Medical University - Sofia, Bulgaria
}

Received: 25.11.2020; Accepted: 17.12.2020; Published: 20.12.2020

\begin{tabular}{|c|c|}
\hline Keywords: & medical education, research, COVID-19 \\
\hline Copyright: & $\begin{array}{l}\text { (C) } 2020 \text { Georgieva L. M., Borisova B. V. Published by Archives of International } \\
\text { Journal of Science Annals }\end{array}$ \\
\hline DOI and UDC & DOI 10.26697/ijsa.2020.2.5; UDC 37.014.5:614.441/.442 \\
\hline Conflict of interests: & The authors declare that there is no conflict of interests \\
\hline Source of support: & This study did not receive any outside funding or support \\
\hline $\begin{array}{l}\text { Information about } \\
\text { the authors: }\end{array}$ & $\begin{array}{l}\text { Georgieva Lidia Mladenova (Corresponding Author) - https://orcid.org/0000-0002- } \\
\text { 9320-9203, lidia1001@gmail.com; Doctor of Philosophy in Medicine, MD, Professor, } \\
\text { Department of Social Medicine, Medical University - Sofia, Bulgaria. }\end{array}$ \\
\hline & $\begin{array}{l}\text { Borisova Boryana Veselinova - https://orcid.org/0000-0001-9199-153X; Doctor of } \\
\text { Philosophy in Medicine, Associate Professor, Department of Health Policy and } \\
\text { Management, Medical University - Sofia, Bulgaria. }\end{array}$ \\
\hline
\end{tabular}

\section{Dear Editor,}

In days of Global and national stress-tragedies, when what we considered to be a stable value is shaken, our eyes turn to a critical rethinking of the past. Today's reality needs more than ever not only urgent practical procedures, restrictions, etc., but a very deep and unified concept and strategy based on sound philosophy and analyses.

Evidence-based practical action is the philosophy of our behavior today. But do we have enough evidence and what are they? This is the question that still has no definite answers.

Medicine is rightly proud of many of its achievements. But today, her pride is overshadowed by her inability to defeat a microscopic invisible enemy of human health. We must be honest: it turned out that medicine is strong in new modern technologies, but it is powerless to manage an invisible enemy, massively threatening the health of the Planet. It turned out that medicine is poorly prepared for surprises - not only to meet them, but also to anticipate them.

Medicine is an art of probability and it must permanently prove the most probable predictions and the most effective actions.

Now, by accident, the means used are mainly from the middle of the twentieth Century, from this classic epidemiology that we had forgotten. But now we are not the twentieth Century, and the media constantly suggests to us as fateful paths "social distance" and "social isolation". Are these the main or only means of saving the population in the 21st Century? And how will a society live through social isolation?
The wise people have always given the formula "We are all in God's hands", in crisis situations. This formula actually reflects a fundamental natural law - only the great Nature, of which we are a part, will save us. Even the great Hippocrates advised the doctor: "Support the forces of nature".

And against viruses, the greatest power of Nature is in ourselves - in our immune system. Yes, but caring for the nation's immunity would be an even more difficult task for politicians and medical professionals, because it implies larger measures for a rational style and standard of living. But how can this happen?

Preventive medicine has been on the periphery of the minds of health policymakers, in recent decades. It is formally mentioned in International (World Health Organization \& United Nations Children's Fund, 2018) and national strategies, but it is not a de facto priority and pales in comparison to the dictates of clinical medicine. The message of the famous Russian surgeon Nikolai Pirogov that says "the future belongs to preventive medicine" (Komarov \& Fishman, 2019; Pirogov, 1961), wait for the future, yet.

In the modern research and especially in medical education is extremely underestimated the discipline of epidemiology of infectious diseases, sunk in the shadow of the so-called epidemiology of non-communicable diseases. For 4-5 decades, physicians have been taught that infectious diseases as a cause of death have gone down in history - which was a fact for some time, but now life tells us that history is a cycle, that medical science is far from health prognosis. 
Future doctors are extremely limited in their training and education on preventive and health-organizational disciplines such as health policy and management, promotion of health, public health culture and health behavior, hygiene, immunology, nutrition, medical globalization, medical prognosis etc.

Obviously, medical science and education also need accelerated creativity and development of new medical disciplines and directions, along with modern technologies.

Against this background, it is not surprising that worldwide there is no unified proven concept of an active offensive strategy in the fight against viruses in general. The big hope is for the vaccines now! But we already lost more than 1397139 lives, out of 59204902 confirmed cases of COVID-19, reported by WHO Globally, so far (25 November 2020) (World Health Organization, 2020), due to the small creature and we continue loosing every minute more and more.

It is quite difficult to predict what future lessons the current pandemic with the COVID-19 virus will give us. But we will allow the conviction that two lessons are already visible today:

1. The need for an urgent cardinal revolution in the scientific and educational sector of medicine is already felt. Recent research in this area makes this belief even more grounded (Melnyk, Pypenko, \& Maslov, 2020).

2. Global awareness of the need to urgently mobilize the entire scientific medical potential of the Planet to discover a new preventive and curative era in the fight against viruses, similar to the victory over smallpox, malaria, etc., but especially similar to the antibiotic era created by Fleming in 1928.
Escape and hide from viruses should be replaced by a successful victory over them.

\section{Acknowledgements}

The authors acknowledge the inspiration by Prof. Veselin Borisov.

\section{References}

Komarov, Y., \& Fishman, B. (2019). The problem of transition from curative to preventive medicine in the 21st century (A brief overview of the state of medicine at the present stage). American Journal of Biomedical Science \& Research, 4(5), 329-331. doi:10.34297/AJBSR.2019.04.000828

Melnyk, Yu. B., Pypenko, I. S., \& Maslov, Yu. V. (2020). CoVID-19 pandemic as a factor revolutionizing the industry of higher education. Rupkatha Journal, 12(5). doi:10.21659/rupkatha.v12n5.rioc1s19n2

Pirogov, N. I. (1961). Nachala obshhej voenno-polevoj hirurgii [The beginnings of general military field surgery] (Vol. 5). Moscow: Medgiz. [in Russian]

World Health Organization, \& United Nations Children's Fund. (2018). A vision for primary health care in the 21st century: Towards universal health coverage and the Sustainable Development Goals. Geneva: World Health Organization and the United Nations Children's Fund (UNICEF). Retrieved from https://www.who.int/docs/defaultsource/primary-health/vision.pdf

World Health Organization. (2020). WHO Coronavirus Disease (COVID-19) Dashboard. Retrieved from https://covid19.who.int/

\section{Cite this article as:}

Georgieva, L. M., \& Borisova, B. V. (2020). An Invisible Virus Has Made Visible Many Underestimated Problems in Medical Education and Research. International Journal of Science Annals, 3(2), 34-35. doi:10.26697/ijsa.2020.2.5

The electronic version of this article is complete. It can be found online in the IJSA Archive https://ijsa.culturehealth.org/en/arhiv and in the KRPOCH Publishing Repository https://ekrpoch.culturehealth.org/handle/lib/71 This is an Open Access article distributed under the terms of the Creative Commons Attribution License, which permits unrestricted use, distribution, and reproduction in any medium, provided the original work is properly cited (http://creativecommons.org/licenses/by/4.0/deed.en). 